\title{
The epidemiology of venous thromboembolism
}

\author{
John A. Heit ${ }^{1} \cdot$ Frederick A. Spencer $^{2} \cdot$ Richard H. White $^{3}$
}

Published online: 16 January 2016

(c) The Author(s) 2016. This article is published with open access at Springerlink.com

\begin{abstract}
Venous thromboembolism (VTE) is categorized by the U.S. Surgeon General as a major public health problem. VTE is relatively common and associated with reduced survival and substantial health-care costs, and recurs frequently. VTE is a complex (multifactorial) disease, involving interactions between acquired or inherited predispositions to thrombosis and VTE risk factors, including increasing patient age and obesity, hospitalization for surgery or acute illness, nursing-home confinement, active cancer, trauma or fracture, immobility or leg paresis, superficial vein thrombosis, and, in women, pregnancy and puerperium, oral contraception, and hormone therapy. Although independent VTE risk factors and predictors of VTE recurrence have been identified, and effective primary and secondary prophylaxis is available, the occurrence of VTE seems to be relatively constant, or even increasing.
\end{abstract}

Keywords Venous thromboembolism · Pulmonary embolism - Deep vein thrombosis - Thrombophlebitis . Epidemiology

John A. Heit

heit.john@mayo.edu

1 Division of Cardiovascular Diseases (JAH), Mayo Clinic, Hematology Research-Stabile 660, 200 First Street SW, Rochester, MN 55905, USA

2 Division of Cardiology (FAS), McMaster University, Hamilton, ON, USA

3 Division of General Internal Medicine (RHW), University of California, Davis, Sacramento, CA, USA

\section{Introduction}

Thrombosis can affect virtually any venous circulation. This chapter focuses on the epidemiology of venous thromboembolism (VTE), including deep vein thrombosis (DVT) of the leg or pelvis, and its complication, pulmonary embolism (PE). Thrombosis affecting the superficial leg (e.g. saphenous) veins and other venous circulations (e.g. arm, cerebral, mesenteric, renal, hepatic, portal veins) is beyond the scope of this chapter. VTE is a complex (multifactorial) disease, involving interaction between acquired or inherited predispositions to thrombosis (i.e. thrombophilia) and environmental exposures (i.e. clinical risk factors) [1-5]. Moreover, the type of VTE event (PE vs. DVT) may also be partly heritable [6, 7]. Most studies of VTE epidemiology addressed populations of predominantly European origin, and the data discussed in this chapter mainly relate to these populations. Where available, data from populations originating from other continents are presented.

\section{Methods}

This chapter focuses on population-based studies and addresses nine questions regarding the epidemiology of VTE (Table 1). Questions were developed by consensus from the authors. The literature addressing the above questions was reviewed by searching electronic databases (PubMed, Medline), including the references of all identified papers and the author's personal libraries. Since this review is informational only and does not address diagnosis, treatment or management of VTE, there are no associated guidance statements. The post thrombotic syndrome and the epidemiology of inherited and acquired 
Table 1 Guidance questions to be considered

(1) What is the incidence of VTE, PE with or without ( \pm ) DVT and leg DVT alone, both overall, and by age, sex and race, and by idiopathic versus secondary VTE?

(2) What are the trends in incidence over time of overall VTE, leg DVT alone and PE \pm DVT, and of idiopathic versus secondary VTE? How are these trends affected by changes in diagnostic test utilization, imaging resolution and autopsy rates over time?

(3) What is the cumulative incidence of VTE recurrence, both overall and by leg DVT alone versus PE \pm DVT?

(4) What baseline and time-dependent characteristics are independent predictors of VTE recurrence after adjustment for primary treatment and secondary prophylaxis? Within the major predictors of VTE recurrence, can the individual patient be further stratified into high and low risk? How well do available VTE recurrence risk-prediction scores operate in predicting recurrence?

(5) What are the attack rates (i.e. incident and recurrent VTE) of VTE, both overall and by hospitalization-related versus community-acquired VTE? What is the total number of VTE events (incident and recurrent) per year in the USA?

(6) What are the VTE-attributable costs?

(7) What is the survival after VTE overall, and after leg DVT alone vs. PE \pm DVT. What are the independent predictors of survival? What are the trends in survival over time after PE \pm DVT?

(8) What are the independent risk factors for VTE? How well do incident VTE risk prediction scores operate in predicting incident VTE for the individual?

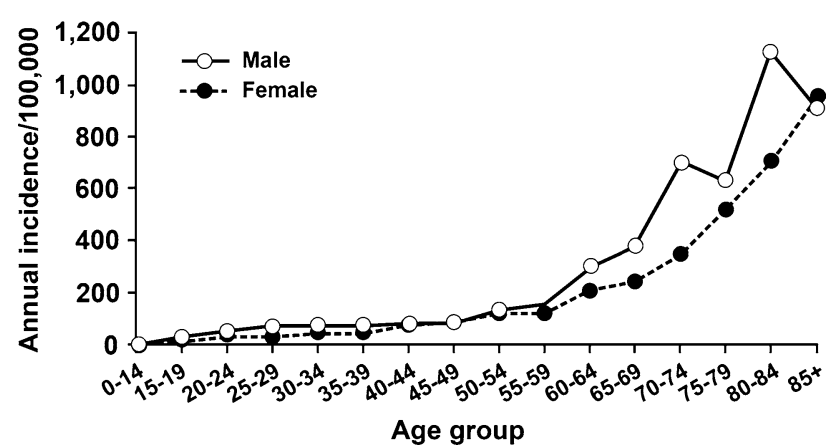

Fig. 1 Annual incidence of venous thromboembolism by age and sex [10]

thrombophilia are reviewed in Chapters 9 and 10, respectively.

\section{Questions}

(1) What is the incidence of VTE, PE with or without $( \pm)$ DVT and leg DVT alone, both overall, and by age, sex and race, and by idiopathic versus secondary VTE?

The estimated average annual incidence rate of overall VTE among persons of European ancestry ranges from 104 to 183 per 100,000 person-years [8-18]; overall VTE incidence is similar to that of stroke $[19,20]$. Overall VTE incidence may be higher in African-Americans [21-23] and lower in Asians [24], and Asian- [25, 26] and NativeAmericans [27], and may differ among African-Americans by United States region [23]. Reported incidence rates for $\mathrm{PE} \pm \mathrm{DVT}$, and for leg DVT alone, range from 29 to 78 ,

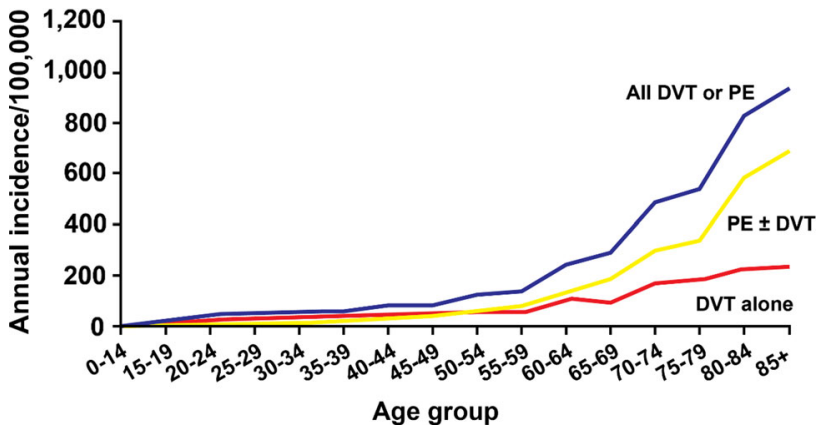

Fig. 2 Annual incidence of all venous thromboembolism, deep vein thrombosis (DVT) alone, and pulmonary embolism with or without deep vein thrombosis (PE \pm DVT) by age [10]

and 45 to 117 , per 100,000 person-years, respectively [10, 12, 14-18].

VTE is predominantly a disease of older age; VTE is rare prior to late adolescence $[8,10-15,18]$. Incidence rates increase markedly with age for both men and women (Fig. 1) and for both DVT and PE (Fig. 2) [10, 14, 15]. The overall age-adjusted incidence rate is higher for men (130 per 100,000) then women (110 per 100,000; male:female sex ratio is 1.2:1) [10,15]. Incidence rates are somewhat higher in women during childbearing years, while incidence rates after age 45 years are generally higher in men. PE accounts for an increasing proportion of VTE with increasing age for both sexes [10]. The percentage of incident VTE events that are idiopathic ranges from 25 to $40 \%$ [26, 28, 29]. In one study, $19 \%$ of events among Asian/Pacific Islanders were idiopathic [26].

(2) What are the trends in incidence over time of overall VTE, leg DVT alone and PE \pm DVT, and of idiopathic versus secondary VTE? How are these trends 


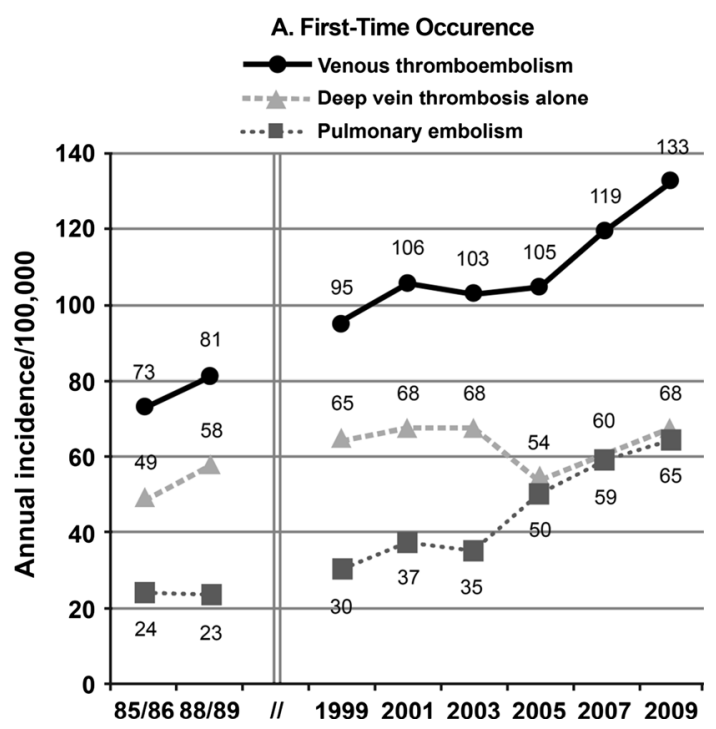

Fig. 3 Secular trends in the incidence of venous thromboembolism, deep vein thrombosis alone, and pulmonary embolism [18]

affected by changes in diagnostic test utilization, imaging resolution and autopsy rates over time?

Data on trends in VTE incidence are limited; overall VTE incidence rates as well as incidence rates for $\mathrm{PE} \pm \mathrm{DVT}$ and DVT alone either remained relatively constant or increased for the period, 1981-2000, with a significant increase in the overall VTE incidence rate from 2001 to 2009, mostly due to an increasing incidence of PE \pm DVT (Fig. 3) $[10,14,18,30]$. The incidence rates of incident cancer-associated VTE, secondary non cancerassociated VTE and idiopathic VTE, 1999-2009, appear to be relatively constant [29]. The observed increase in overall VTE and PE \pm DVT incidence rates over the most recent time period may, in part, reflect increased utilization of objective imaging and improved image resolution, particularly computed tomography, pulmonary angiography, and magnetic resonance imaging [18].

(3) What is the cumulative incidence of VTE recurrence, both overall and by leg DVT alone vs. $\mathrm{PE} \pm \mathrm{DVT}$ ?

VTE recurs frequently; about $30 \%$ of patients develop recurrence within the next 10 years (Fig. 4) [16, 31-41]; reported incidence rates of recurrent overall VTE, $\mathrm{PE} \pm$ DVT and DVT alone range from 19 to 39, 4-13, and 15 to 29 per 100,000 person-years, respectively [18]. The hazard of recurrence varies with the time since the incident event and is highest within the first 6-12 months but never falls to zero. While secondary prophylaxis is effective in preventing recurrence, the duration of acute treatment does not affect the rate of recurrence after three months of adequate anticoagulation has been completed [34, 35, 42-

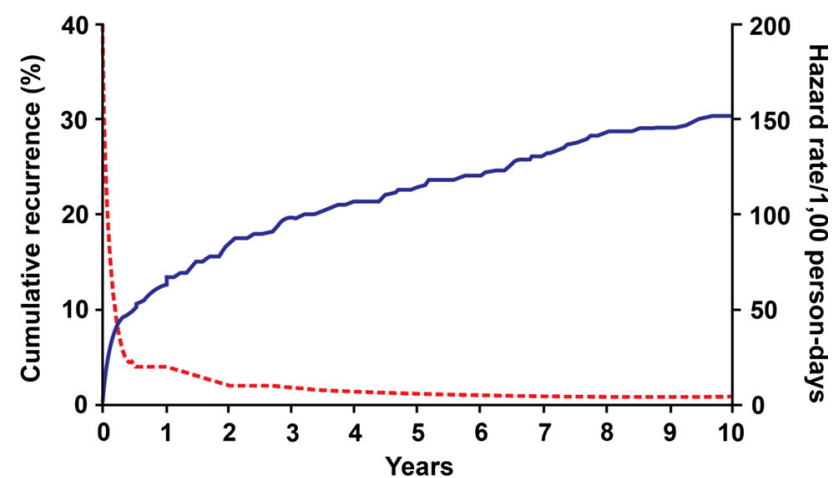

Fig. 4 Cumulative incidence of first venous thromboembolism recurrence (continuous line), and the hazard of first recurrence per 1000 person-days (dotted line) [32]

46]. These data suggest that VTE is a chronic disease with episodic recurrence [32, 33, 47, 48].

(4) What baseline and time-dependent characteristics are independent predictors of VTE recurrence after adjustment for primary treatment and secondary prophylaxis? Within the major predictors of VTE recurrence, can the individual patient be further stratified into high and low risk? How well do available VTE recurrence risk-prediction scores operate in predicting recurrence?

Independent predictors of recurrence include increasing patient age (per 10 years $[32,33,35,36,49-54]$ and body mass index (per $10 \mathrm{~kg} / \mathrm{m}^{2}$ ) [32, 52, 54-57] male sex [32, $35,51,57-65]$, active cancer [12, 31, 32, 49, 66-71], and neurologic disease with leg paresis [32]. Additional predictors of recurrence include idiopathic VTE [31, 36, 44, $59,67,68,72-74]$, a lupus anticoagulant or antiphospholipid antibody $[43,75]$, antithrombin, protein $\mathrm{C}$ or protein $\mathrm{S}$ deficiency [76-78], hyperhomocysteinemia [79], a persistently increased plasma D-dimer among patients with idiopathic VTE [80-83], and possibly residual vein thrombosis [84, 85]. Among active cancer patients, VTE recurrence risk can be further stratified by cancer site (pancreatic, brain, lung and ovarian cancer, myeloproliferative or myelodysplastic disorders), stage IV cancer, cancer stage progression and leg paresis [71].

Of equal importance, several risk factors present at the time of the incident VTE event are associated with either a reduced risk of recurrence or are not predictive of recurrence $[31-33,45,59,86]$. For women, pregnancy or the postpartum state [32, 39], oral contraceptive use [32], hormone therapy [63, 87], and gynecologic surgery [32] are associated with a reduced risk of recurrence. Recent surgery and trauma/fracture either have no effect [32] or predict a reduced risk of recurrence [31, 88]. Additional characteristics having no significant effect on recurrence risk include recent immobilization, tamoxifen therapy, and 
failed prophylaxis [32]. For these patients, and for patients with isolated calf vein thrombosis, a shorter duration (i.e., 6 weeks) of acute therapy likely is adequate [45, 67]. While data on the type of incident event type (DVT alone vs. PE \pm DVT) as a predictor of recurrence are conflicting [32, 36, 37, 45, 50, 57, 89-92], patients with a recurrent event are significantly more likely to have the same type of VTE event as the incident event type [50].

Several VTE recurrence prediction scores have been derived for stratifying recurrence risk among patients with incident idiopathic or cancer-associated VTE. In the "Men continue and HERDOO2" score, there were no predictors of a reduced risk of recurrence among men with incident idiopathic VTE. In contrast, women with idiopathic VTE who had $\leq 1$ of the following risk factors had a significantly lower risk of VTE recurrence: (1) older age ( $\geq 65$ years), (2) obesity (BMI $\geq 30 \mathrm{~kg} / \mathrm{m}^{2}$ ), (3) an increased D-dimer prior to stopping warfarin therapy and (4) signs of post thrombotic syndrome [93]. In the Vienna prediction model, male sex, incident VTE site (PE and proximal DVT vs. isolated calf DVT) and increasing D-dimer level were predictors of recurrence after idiopathic incident VTE [94]. In the DASH prediction score, a persistently increased D-dimer after stopping anticoagulation therapy, age $<50$ years, male sex and VTE unrelated to hormonal therapy (in women) predicted an increased risk of recurrence after an "idiopathic" incident VTE [95]. Thus, the only inconsistent risk factor in these models is the effect of patient age, with older and younger age being associated with a higher recurrence risk among women in the HERDOO2 model and among men and women in the DASH model, respectively [93, 95], while patient age was not a predictor of recurrence in the Vienna model [94]. Depending on the model, patients with a low score had 1.6-4.4\% per year recurrence rates [96, 97]. Assuming these recurrence rates are acceptable, about $50 \%$ of patients with idiopathic incident VTE and a low prediction score could avoid secondary prophylaxis [93-95]. Among active cancer patients with VTE, patient sex, cancer site (lung, breast), cancer stage and prior VTE were predictors of VTE recurrence while on anticoagulation therapy [70, 98].

(5) What are the attack rates (i.e. incident and recurrent VTE) of VTE, both overall and by hospitalizationrelated versus community-acquired VTE? What is the total number of VTE events (incident and recurrent) per year in the USA?

Estimated overall VTE attack rates range from 142 to over 300 per 100,000 person-years; estimated attack rates for PE \pm DVT and DVT alone range from 51 to 75 and 91 to 255 per 100,000 , respectively [18, 99]. Overall VTE attack rates related to current or recent hospitalization are much higher compared to rates among persons residing in the community (330 vs. 8 per 100,000 , respectively) [99].

There are few data on the total number of VTE events (incident and recurrent) occurring in the USA per year, and available estimates vary widely. Using age- and sexspecific incidence rates for the five-year time period, 1991-95, projected to the 2000 United States white population, at least 260,000 first-lifetime cases of VTE occur among whites in the United States annually [13]. If incidence rates among African-Americans are similar, then 27,000 additional incident cases occur among AfricanAmericans in the United States annually. In an incidencebased modeling study that included both hospital- and community-acquired, incident and recurrent VTE events, an estimated 600,000 non-fatal VTE events (370,000 DVT and 270,000 PE) occurred in the USA in 2005; of the total, approximately two-thirds were related to current or recent hospitalization [13]. Using 2007-2009 National Hospital Discharge Survey discharge diagnosis codes, an estimated average of about 548,000 hospitalizations with VTE occurred each year among USA residents aged $\geq 18$ years, of which 349,000 were DVT and 278,000 were PE [100].

\section{(6) What are the VTE-attributable costs?}

In population-based studies, the adjusted mean predicted costs were 2.5-fold higher for patients with VTE related to current or recent hospitalization for acute medical illness $(\$ 62,838)$ compared to hospitalized controls matched on active cancer status $(\$ 24,464 ; \mathrm{p}<0.001)$ from the VTE event date (or index date for controls) to 5 years post index; cost differences between cases and controls were greatest within the first 3 months (mean difference $=\$ 16,897$ ) [101]. Similarly, the adjusted mean predicted costs were 1.5-fold higher for patients with VTE related to current or recent hospitalization for major surgery $(\$ 55,956)$ compared to hospitalized controls matched to cases on type of surgery and active cancer status $(\$ 32,718 ; \mathrm{p}<0.001)$ from the VTE event date (or index date for controls) to 5 years post index [102]. Cost differences between cases and controls were also greatest within the first 3 months after index (mean difference $=\$ 12,381)$. Costs were significantly higher for cases than controls (mean difference $=\$ 10,797$ ) from 3 months to up to 5 years post-index and together accounted for about half of the overall cost difference. Finally, the adjusted mean predicted costs were over 2-fold higher for patients with VTE related to active cancer $(\$ 52,422)$ compared to active cancer controls matched on the duration of active cancer $(\$ 23,951 ; \mathrm{p}<0.001)$ from the VTE event date (or index date for controls) to 5 years post index [103]. Cost differences between cases and controls were greatest within the first 3 months (mean difference $=\$ 16,488$ ) but remained significantly higher for up to 4 years after index. 
Table 2 Survival (\%) after deep vein thrombosis vs. pulmonary embolism [104]

\begin{tabular}{lll}
\hline Time & Deep vein thrombosis alone & Pulmonary embolism \\
\hline 0 days & 97.0 & 76.5 \\
7 days & 96.2 & 71.1 \\
14 days & 95.7 & 68.7 \\
30 days & 94.5 & 66.8 \\
90 days & 91.9 & 62.8 \\
1 year & 85.4 & 57.4 \\
2 years & 81.4 & 53.6 \\
5 years & 72.6 & 47.4 \\
8 years & 65.2 & 41.5 \\
\hline
\end{tabular}

(7) What is the survival after VTE overall, and after leg DVT alone vs. PE \pm DVT. What are the independent predictors of survival? What are the trends in survival over time after PE \pm DVT?

Overall, survival after VTE is worse than expected, and survival after PE is much worse than after DVT alone (Table 2) [37, 104-107]. The risk of early death among PE patients is 18-fold higher compared with patients with DVT alone [104]. Pulmonary embolism is an independent predictor of reduced survival for up to 3 months after onset. After 3 months, observed survival after PE is similar to expected survival $[15,104,105]$. For almost one-quarter of PE patients, the initial clinical presentation is sudden death [104]. Independent predictors of reduced early survival after VTE include increasing age, male sex, lower body mass index, confinement to a hospital or nursing home at VTE onset, congestive heart failure, chronic lung disease, serious neurologic disease, and active cancer [41, 104, 105, 108]. Additional clinical predictors of poor early survival after PE include syncope and arterial hypotension [108, 109]. Evidence of right heart failure based on clinical examination, plasma markers (e.g. cardiac troponin $\mathrm{T}$, brain natriuretic peptide) or echocardiography predicts poor survival among normotensive PE patients [108]. Survival over time may be improving for those PE patients living sufficiently long to be diagnosed and treated [104, $106,110,111]$.

(8) What are the independent risk factors for VTE? How well do incident VTE risk prediction scores operate in predicting incident VTE for the individual?

Independent risk factors for VTE include increasing patient age and body mass index, major surgery, hospitalization for acute medical illness, nursing home confinement, trauma/fracture, active cancer with or without concurrent chemotherapy, central vein catheterization or transvenous pacemaker, prior superficial vein thrombosis,
Table 3 Independent risk factors for deep vein thrombosis or pulmonary embolism [117]

\begin{tabular}{lll}
\hline Baseline characteristic & Odds ratio & $95 \% \mathrm{CI}$ \\
\hline Body mass index $\left(\mathrm{kg} / \mathrm{m}^{2}\right)$ & 1.08 & $1.05,1.11$ \\
Major surgery & 18.95 & $9.22,38.97$ \\
Hospitalization for acute medical illness & 5.07 & $3.12,8.23$ \\
Nursing home confinement & 4.63 & $2.77,7.74$ \\
Trauma/fracture & 4.56 & $2.46,8.46$ \\
Active cancer & 14.64 & $7.73,27.73$ \\
Neurologic disease with leg paresis & 6.10 & $1.97,18.89$ \\
Pregnancy or postpartum & 4.24 & $1.30,13.84$ \\
Oral contraceptives & 4.03 & $1.83,8.89$ \\
Estrogen alone & 1.81 & $1.06,3.09$ \\
Non-contraceptive estrogen plus progestin & 2.53 & $1.38,4.63$ \\
\hline
\end{tabular}

varicose veins, neurologic disease with leg paresis, urinary tract infection, an increased baseline plasma fibrin D-dimer and family history of venous thromboembolism; patients with chronic liver disease have a reduced risk (Table 3) [112-118]. Compared to residents in the community, hospitalized residents have over a 100 -fold increased incidence of VTE [119]. Hospitalization and nursing home residence together account for almost $60 \%$ of incident VTE events occurring in the community $[28,120]$. Of note, hospitalization for medical illness and hospitalization for surgery account for almost equal proportions of VTE (22 and $24 \%$, respectively). Nursing home residence independently accounts for over one-tenth of all VTE disease in the community $[28,120]$.

VTE risk among surgery patients can be further stratified based on patient age, type of surgery, smoking and the presence of active cancer [121-123]. The incidence of postoperative VTE is increased for surgery patients $\geq 65$ years of age [124]. High VTE-risk surgical procedures include neurosurgery, major orthopedic surgery of the leg, thoracic, abdominal or pelvic surgery for cancer, renal transplantation, and cardiovascular surgery [115, 124, 125]. Obesity [126-129], and poor American Society of Anesthesiology physical status [130] are risk factors for VTE after total hip arthroplasty.

VTE risk among patients hospitalized for acute medical illness may be further stratified based on increasing patient age, obesity, previous VTE, thrombophilia, cancer, recent trauma or surgery, tachycardia, acute myocardial infarction or stroke, leg paresis, congestive heart failure, prolonged immobilization (bed rest), acute infection or rheumatologic disorder, hormone therapy, central venous catheter, admission to an intensive or coronary care unit, white blood cell count and platelet count [131-137].

While risk assessment models for predicting VTE among hospitalized non-surgical patients have been 
derived, the number, predictor types and strength of association with VTE are highly variable and lack generalizability and adequate validation [138, 139].

Active cancer accounts for almost $20 \%$ of all incident VTE occurring in the community [28, 120]. The risk appears to be higher for patients with cancer of the brain, pancreas, ovary, colon, stomach, lung, kidney and bone [140, 141], and in patients with distant metastases [141]. Cancer patients receiving immunosuppressive or cytotoxic chemotherapy are at even higher risk for VTE [112, 141], including therapy with L-aspariginase [142, 143], thalidomide [144] or lenalidomide [145], or tamoxifen [146]. Routine screening for occult cancer is controversial and likely not warranted. However, if clinical features suggest a possible occult cancer (i.e. idiopathic VTE, especially among patients with abdominal vein or bilateral leg vein thrombosis [147] or in whom VTE recurs [148]) then the only imaging study shown to be useful is a CT scan of the abdomen and pelvis [148]. Among cancer patients, the risk of chemotherapy-associated VTE is increased in patients with pancreatic or gastric cancer, platelet count $\geq 350 \times$ $10^{9} / \mathrm{L}$, hemoglobin $<100 \mathrm{~g} / \mathrm{L}$ or use of red cell growth factors, leukocyte count $\geq 11 \times 10^{9} / \mathrm{L}$, or body mass index $\geq 35 \mathrm{~kg} / \mathrm{m}^{2}$ [149]; biomarkers (plasma soluble P-selectin and D-dimer) add further predictive value [150].

A central venous catheter or transvenous pacemaker accounts for $9 \%$ of all incident VTE occurring in the community [28]. Central venous access via femoral vein catheters is associated with a higher incidence of VTE compared to subclavian vein catheterization [151]. Prior superficial vein thrombosis is an independent risk factor for subsequent DVT or PE remote from the episode of superficial thrombophlebitis $[112,152]$. The risk of DVT imparted by varicose veins is uncertain and appears to vary by patient age [112, $153,154]$. Long haul $(>4-6 \mathrm{~h})$ air travel is associated with a slightly increased risk for VTE ( $\sim 1$ per 4656 flights [155157]) that is preventable with elastic stockings [158]. HMGCoenzyme A reductase inhibitor (statin) therapy may provide a 20-50 \% risk reduction for VTE [159-161]. Hypertriglyceridemia doubles the risk of VTE in postmenopausal women [162]. However, the risk associated with atherosclerosis, or other risk factors for atherosclerosis, remains uncertain [118, 163-167]. Diabetes mellitus [117], myocardial infarction [168], current or past tobacco smoking, high-density lipoprotein cholesterol, lipoprotein (a), chronic obstructive pulmonary disease, and renal failure are not independent risk factors for VTE $[112,169,170]$. The risk associated with congestive heart failure, independent of hospitalization, is low $[112,121]$.

Among women, additional risk factors for VTE include oral contraceptive use $[117,121,171-173]$, hormone therapy $[117,174,175]$, pregnancy and the postpartum period $[121,172,176]$, and therapy with the selective estrogen receptor modulator, raloxifene [177]. First and third generation oral contraceptives convey higher risk than second generation oral contraceptives [173]. Injectable depot-medroxyprogesterone acetate for contraception is associated with a three-fold increased risk for venous thromboembolism, while a levonorgestrel intrauterine device imparts no risk [178]. Hormone therapy is associated with a 2- to fourfold increased risk of VTE [117, 174], but the risk may vary by type of estrogen [179] and there may be no risk with transdermal estrogen therapy [180]. The overall incidence of pregnancy-associated VTE is about 200 per 100,000 woman-years; compared to nonpregnant women of childbearing age, the relative risk is increased about fourfold [176, 181]. The risk during the postpartum period is about fivefold higher than the risk during pregnancy [176]. Prior superficial vein thrombosis is an independent risk factor for VTE during pregnancy or postpartum [182, 183].

Other conditions associated with VTE include autoimmune disorders [167], Behcet's syndrome, celiac disease [184], heparin-induced thrombocytopenia [185], homocystinuria and hyperhomocysteinemia [186, 187], hyperthyroidism [188], immune thrombocytopenia (ITP) [189, 190], infection [114], inflammatory bowel disease [191], intravascular coagulation and fibrinolysis/disseminated intravascular coagulation (ICF/DIC), myeloproliferative disorders (especially polycythemia rubra vera and essential thrombocythemia) [192, 193], chronic kidney disease with severely reduced glomerular filtration rate [194], nephrotic syndrome [195], paroxysmal nocturnal hemoglobinuria [196], rheumatoid arthritis [197, 198], obstructive sleep apnea [199, 200], thromboangiitis obliterans (Buerger's disease), thrombotic thrombocytopenic purpura, sickle cell disease [201], systemic lupus erythematosus, and granulomatosis with polyangiitis (Wegener's) [202].

Acknowledgments We wish to acknowledge the support provided by Myelin and Associates with the preparation of this manuscript for submission. The work contained in this manuscript was partially funded by support from the following companies: Boehringer Ingelheim, Daiichi Sankyo and Janssen Pharmaceuticals. This guidance document is endorsed by the Anticoagulation Forum's Board of Directors: Mark Crowther, MD, MSc, FRCPC, Jack E. Ansell, MD, Allison Burnett, PharmD, Nathan Clark, PharmD, Adam Cuker, MD, David Garcia, MD, Scott Kaatz, DO, MSc, FACP, Renato D. Lopes, $\mathrm{MD}, \mathrm{PhD}$, Tracy Minichiello, MD, Edith Nutescu, PharmD, FCCP, Lynn Oertel, MS, ANP, CACP, Eva Kline-Rogers, MS, RN, NP,Terri Schnurr, RN, CCRC, Michael Streiff, MD, Diane Wirth, ANP, CACP, BCPS, CACP, Daniel Witt, Pharm D, Ann Wittkowsky, PharmD, CACP, FASHP, FCCP.

\section{Compliance with ethical standards}

Disclosures J. Heit has no disclosures. R White has attended advisory meetings with Boehringer-Ingleheim, Janssen, BristolMeyer-Squibb, and Daiichi Sankyo. Has participated in clinical epidemiology research with Daiichi-Sankyo. F Spencer has No pertinent 
conflicts of interest. Only recent outside payments from UpToDate for a chapter on Aspirin in Primary Prevention of Cardiovascular Disease and Malignancy $(<2 \mathrm{~K})$. Potential intellectual conflicts of interest are prior NIH grants for study of venous thromboembolism epidemiology.

Open Access This article is distributed under the terms of the Creative Commons Attribution 4.0 International License (http://crea tivecommons.org/licenses/by/4.0/), which permits unrestricted use, distribution, and reproduction in any medium, provided you give appropriate credit to the original author(s) and the source, provide a link to the Creative Commons license, and indicate if changes were made.

\section{References}

1. Souto JC, Almasy L, Borrell M et al (2000) Genetic susceptibility to thrombosis and its relationship to physiological risk factors: the GAIT study. Genetic Analysis of Idiopathic Thrombophilia. Am J Hum Genet 67:1452-1459

2. Ariens RA, de Lange M, Snieder H, Boothby M, Spector TD, Grant PJ (2002) Activation markers of coagulation and fibrinolysis in twins: heritability of the prethrombotic state. Lancet 359:667-671

3. Larsen TB, Sorensen HT, Skytthe A, Johnsen SP, Vaupel JW, Christensen K (2003) Major genetic susceptibility for venous thromboembolism in men: a study of Danish twins. Epidemiology 14:328-332

4. Heit JA, Phelps MA, Ward SA, Slusser JP, Petterson TM, De Andrade M (2004) Familial segregation of venous thromboembolism. J Thromb Haemost 2:731-736

5. Zoller B, Ohlsson H, Sundquist J, Sundquist K (2013) Familial risk of venous thromboembolism in first-, second- and thirddegree relatives: a nationwide family study in Sweden. Thromb Haemost 109:458-463

6. Zoller B, Li X, Sundquist J, Sundquist K (2012) A nationwide family study of pulmonary embolism: identification of high risk families with increased risk of hospitalized and fatal pulmonary embolism. Thromb Res 130:178-182

7. Zoller B, Li X, Sundquist J, Sundquist K (2012) Shared familial aggregation of susceptibility to different manifestations of venous thromboembolism: a nationwide family study in Sweden. Br J Haematol 157:146-148

8. Anderson FA Jr, Wheeler HB, Goldberg RJ et al (1991) A population-based perspective of the hospital incidence and casefatality rates of deep vein thrombosis and pulmonary embolism. The Worcester DVT Study. Arch Intern Med 151:933-938

9. Hansson PO, Welin L, Tibblin G, Eriksson H (1997) Deep vein thrombosis and pulmonary embolism in the general population. 'The Study of Men Born in 1913'. Arch Intern Med 157:1665-1670

10. Silverstein MD, Heit JA, Mohr DN, Petterson TM, O'Fallon WM, Melton LJ 3rd (1998) Trends in the incidence of deep vein thrombosis and pulmonary embolism: a 25 -year populationbased study. Arch Intern Med 158:585-593

11. Oger E (2000) Incidence of venous thromboembolism: a community-based study in Western France. EPI-GETBP Study Group. Groupe d'Etude de la Thrombose de Bretagne Occidentale. Thromb Haemost 83:657-660

12. Cushman M, Tsai AW, White RH et al (2004) Deep vein thrombosis and pulmonary embolism in two cohorts: the longitudinal investigation of thromboembolism etiology. Am J Med 117:19-25

13. Heit JA (2005) Venous thromboembolism: disease burden, outcomes and risk factors. J Thromb Haemost 3:1611-1617
14. Spencer FA, Emery C, Lessard D et al (2009) The Worcester Venous Thromboembolism study: a population-based study of the clinical epidemiology of venous thromboembolism. J Gen Intern Med 21:722-727

15. Naess IA, Christiansen SC, Romundstad P, Cannegieter SC, Rosendaal FR, Hammerstrom J (2007) Incidence and mortality of venous thrombosis: a population-based study. J Thromb Haemost 5:692-699

16. Spencer FA, Emery C, Joffe SW et al (2009) Incidence rates, clinical profile, and outcomes of patients with venous thromboembolism. The Worcester VTE study. J Thromb Thrombolysis 28:401-409

17. Tagalakis V, Patenaude V, Kahn SR, Suissa S (2013) Incidence of and mortality from venous thromboembolism in a real-world population: the Q-VTE Study Cohort. Am J Med 126(832):e813e821

18. Huang W, Goldberg RJ, Anderson FA, Kiefe CI, Spencer FA (2014) Secular trends in occurrence of acute venous thromboembolism: the Worcester VTE study (1985-2009). Am J Med 127(829-839):e825

19. Rothwell PM, Coull AJ, Giles MF et al (2004) Change in stroke incidence, mortality, case-fatality, severity, and risk factors in Oxfordshire, UK from 1981 to 2004 (Oxford Vascular Study). Lancet 363:1925-1933

20. Koton S, Schneider AL, Rosamond WD et al (2014) Stroke incidence and mortality trends in US communities, 1987 to 2011. JAMA 312:259-268

21. White RH, Zhou H, Romano PS (1998) Incidence of idiopathic deep venous thrombosis and secondary thromboembolism among ethnic groups in California. Ann Intern Med 128:737-740

22. Schneider D, Lilienfeld DE, Im W (2006) The epidemiology of pulmonary embolism: racial contrasts in incidence and in-hospital case fatality. J Natl Med Assoc 98:1967-1972

23. Zakai NA, McClure LA, Judd SE et al (2014) Racial and regional differences in venous thromboembolism in the United States in 3 cohorts. Circulation 129:1502-1509

24. Cheuk BL, Cheung GC, Cheng SW (2004) Epidemiology of venous thromboembolism in a Chinese population. Br J Surg 91:424-428

25. Klatsky AL, Armstrong MA, Poggi J (2000) Risk of pulmonary embolism and/or deep venous thrombosis in Asian-Americans. Am J Cardiol 85:1334-1337

26. White RH, Zhou H, Murin S, Harvey D (2005) Effect of ethnicity and gender on the incidence of venous thromboembolism in a diverse population in California in 1996. Thromb Haemost 93:298-305

27. Hooper WC, Holman RC, Heit JA, Cobb N (2002) Venous thromboembolism hospitalizations among American Indians and Alaska Natives. Thromb Res 108:273-278

28. Heit JA, O'Fallon WM, Petterson TM et al (2002) Relative impact of risk factors for deep vein thrombosis and pulmonary embolism: a population-based study. Arch Intern Med 162:1245-1248

29. Spencer FA. Personal communication

30. Heit JA, Sobell JL, Li H, Sommer SS (2005) The incidence of venous thromboembolism among Factor V Leiden carriers: a community-based cohort study. JTH 3:305-311

31. Prandoni P, Lensing AW, Cogo A et al (1996) The long-term clinical course of acute deep venous thrombosis. Ann Intern Med 125:1-7

32. Heit JA, Mohr DN, Silverstein MD, Petterson TM, O'Fallon WM, Melton LJ 3rd (2000) Predictors of recurrence after deep vein thrombosis and pulmonary embolism: a population-based cohort study. Arch Intern Med 160:761-768

33. Hansson PO, Sorbo J, Eriksson H (2000) Recurrent venous thromboembolism after deep vein thrombosis: incidence and risk factors. Arch Intern Med 160:769-774 
34. van Dongen CJ, Vink R, Hutten BA, Buller HR, Prins MH (2003) The incidence of recurrent venous thromboembolism after treatment with vitamin $\mathrm{K}$ antagonists in relation to time since first event: a meta-analysis. Arch Intern Med 163:1285-1293

35. Schulman S, Lindmarker P, Holmstrom M et al (2006) Postthrombotic syndrome, recurrence, and death 10 years after the first episode of venous thromboembolism treated with warfarin for 6 weeks or 6 months. JTH 4:734-742

36. Prandoni P, Noventa F, Ghirarduzzi A et al (2007) The risk of recurrent venous thromboembolism after discontinuing anticoagulation in patients with acute proximal deep vein thrombosis or pulmonary embolism. A prospective cohort study in 1,626 patients. Haematologica 92:199-205

37. Spencer FA, Gore JM, Lessard D, Douketis JD, Emery C, Goldberg RJ (2008) Patient outcomes after deep vein thrombosis and pulmonary embolism: the Worcester Venous Thromboembolism Study. Arch Intern Med 168:425-430

38. Nieto JA, Camara T, Gonzalez-Higueras E et al (2008) Clinical outcome of patients with major bleeding after venous thromboembolism. Findings from the RIETE Registry. Thromb Haemost 100:789-796

39. White RH, Chan WS, Zhou H, Ginsberg JS (2008) Recurrent venous thromboembolism after pregnancy-associated versus unprovoked thromboembolism. Thromb Haemost 100:246-252

40. Kyrle PA, Rosendaal FR, Eichinger S (2010) Risk assessment for recurrent venous thrombosis. Lancet 376:2032-2039

41. Verso M, Agnelli G, Ageno W et al (2012) Long-term death and recurrence in patients with acute venous thromboembolism: the MASTER registry. Thromb Res 130:369-373

42. Schulman S, Granqvist S, Holmstrom M et al (1997) The duration of oral anticoagulant therapy after a second episode of venous thromboembolism. The Duration of Anticoagulation Trial Study Group. N Engl J Med 336:393-398

43. Kearon C, Gent M, Hirsh J et al (1999) A comparison of three months of anticoagulation with extended anticoagulation for a first episode of idiopathic venous thromboembolism. N Engl J Med 340:901-907

44. Agnelli G, Prandoni P, Santamaria MG et al (2001) Three months versus one year of oral anticoagulant therapy for idiopathic deep venous thrombosis. Warfarin Optimal Duration Italian Trial Investigators. N Engl J Med 345:165-169

45. Schulman S, Rhedin AS, Lindmarker P et al (1995) A comparison of six weeks with six months of oral anticoagulant therapy after a first episode of venous thromboembolism. Duration of Anticoagulation Trial Study Group. N Engl J Med 332:1661-1665

46. Agnelli G, Prandoni P, Becattini C et al (2003) Extended oral anticoagulant therapy after a first episode of pulmonary embolism. Ann Intern Med 139:19-25

47. Prandoni P, Lensing AW, Prins MH et al (2002) Residual venous thrombosis as a predictive factor of recurrent venous thromboembolism. Ann Intern Med 137:955-960

48. Kyrle PA, Eichinger S (2003) The risk of recurrent venous thromboembolism: the Austrian Study on Recurrent Venous Thromboembolism. Wien Klin Wochenschr 115:471-474

49. Douketis JD, Foster GA, Crowther MA, Prins MH, Ginsberg JS (2000) Clinical risk factors and timing of recurrent venous thromboembolism during the initial 3 months of anticoagulant therapy. Arch Intern Med 160:3431-3436

50. Murin S, Romano PS, White RH (2002) Comparison of outcomes after hospitalization for deep venous thrombosis or pulmonary embolism. Thromb Haemost 88:407-414

51. Kyrle PA, Minar E, Bialonczyk C, Hirschl M, Weltermann A, Eichinger S (2004) The risk of recurrent venous thromboembolism in men and women. $\mathrm{N}$ Engl J Med 350: 2558-2563
52. Laczkovics C, Grafenhofer H, Kaider A et al (2007) Risk of recurrence after a first venous thromboembolic event in young women. Haematologica 92:1201-1207

53. Kim TM, Kim JS, Han SW et al (2009) Clinical predictors of recurrent venous thromboembolism: a single institute experience in Korea. Thromb Res 123:436-443

54. Eichinger S, Hron G, Bialonczyk C et al (2008) Overweight, obesity, and the risk of recurrent venous thromboembolism. Arch Intern Med 168:1678-1683

55. Romualdi E, Squizzato A, Ageno W (2007) Abdominal obesity and the risk of recurrent deep vein thrombosis. Thromb Res 119:687-690

56. Garcia-Fuster MJ, Forner MJ, Fernandez C, Gil J, Vaya A, Maldonado L (2005) Long-term prospective study of recurrent venous thromboembolism in patients younger than 50 years. Pathophysiol Haemost Thromb 34:6-12

57. Heit JA, Cunningham JM, Petterson TM, Armasu SM, Rider DN, DEA M (2011) Genetic variation within the anticoagulant, procoagulant, fibrinolytic and innate immunity pathways as risk factors for venous thromboembolism. JTH 9:1133-1142

58. Agnelli G, Becattini C, Prandoni P (2004) Recurrent venous thromboembolism in men and women. $\mathrm{N}$ Engl $\mathrm{J}$ Med 351:2015-2018

59. Baglin T, Luddington R, Brown K, Baglin C (2003) Incidence of recurrent venous thromboembolism in relation to clinical and thrombophilic risk factors: prospective cohort study. Lancet 362:523-526

60. Baglin T, Luddington R, Brown K, Baglin C (2004) High risk of recurrent venous thromboembolism in men. JTH 2:2152-2155

61. McRae S, Tran H, Schulman S, Ginsberg J, Kearon C (2006) Effect of patient's sex on risk of recurrent venous thromboembolism: a meta-analysis. Lancet 368:371-378

62. Lijfering WM, Veeger NJ, Middeldorp S et al (2009) A lower risk of recurrent venous thrombosis in women compared with men is explained by sex-specific risk factors at time of first venous thrombosis in thrombophilic families. Blood 114:2031-2036

63. Le Gal G, Kovacs MJ, Carrier M et al (2010) Risk of recurrent venous thromboembolism after a first oestrogen-associated episode. Data from the REVERSE cohort study. Thromb Haemost 104:498-503

64. Christiansen SC, Lijfering WM, Helmerhorst FM, Rosendaal FR, Cannegieter SC (2010) Sex difference in risk of recurrent venous thrombosis and the risk profile for a second event. JTH 8:2159-2168

65. Douketis J, Tosetto A, Marcucci M et al (2011) Risk of recurrence after venous thromboembolism in men and women: patient level meta-analysis. BMJ 342:d813

66. Hutten BA, Prins MH, Gent M, Ginsberg J, Tijssen JG, Buller HR (2000) Incidence of recurrent thromboembolic and bleeding complications among patients with venous thromboembolism in relation to both malignancy and achieved international normalized ratio: a retrospective analysis. J Clin Oncol 18:3078-3083

67. Pinede L, Ninet J, Duhaut P et al (2001) Comparison of 3 and 6 months of oral anticoagulant therapy after a first episode of proximal deep vein thrombosis or pulmonary embolism and comparison of 6 and 12 weeks of therapy after isolated calf deep vein thrombosis. Circulation 103:2453-2460

68. Prandoni P, Lensing AW, Piccioli A et al (2002) Recurrent venous thromboembolism and bleeding complications during anticoagulant treatment in patients with cancer and venous thrombosis. Blood 100:3484-3488

69. Louzada ML, Majeed H, Dao V, Wells PS (2011) Risk of recurrent venous thromboembolism according to malignancy characteristics in patients with cancer-associated thrombosis: a systematic review of observational and intervention studies. Blood Coagul Fibrinolysis 22:86-91 
70. Louzada ML, Carrier M, Lazo-Langner A et al (2012) Development of a clinical prediction rule for risk stratification of recurrent venous thromboembolism in patients with cancer-associated venous thromboembolism. Circulation 126:448-454

71. Chee CE, Ashrani AA, Marks RS et al (2014) Predictors of venous thromboembolism recurrence and bleeding among active cancer patients: a population-based cohort study. Blood 123:3972-3978

72. Iorio A, Kearon C, Filippucci E et al (2010) Risk of recurrence after a first episode of symptomatic venous thromboembolism provoked by a transient risk factor: a systematic review. Arch Intern Med 170:1710-1716

73. Baglin T, Douketis J, Tosetto A et al (2010) Does the clinical presentation and extent of venous thrombosis predict likelihood and type of recurrence? A patient-level meta-analysis. JTH $8: 2436-2442$

74. Kovacs MJ, Kahn SR, Wells PS et al (2010) Patients with a first symptomatic unprovoked deep vein thrombosis are at higher risk of recurrent venous thromboembolism than patients with a first unprovoked pulmonary embolism. JTH 8:1926-1932

75. Schulman S, Svenungsson E, Granqvist S (1998) Anticardiolipin antibodies predict early recurrence of thromboembolism and death among patients with venous thromboembolism following anticoagulant therapy. Duration of Anticoagulation Study Group. Am J Med 104:332-338

76. van den Belt AG, Sanson BJ, Simioni P et al (1997) Recurrence of venous thromboembolism in patients with familial thrombophilia. Arch Intern Med 157:2227-2232

77. Vossen CY, Conard J, Fontcuberta J et al (2005) Risk of a first venous thrombotic event in carriers of a familial thrombophilic defect. The European prospective cohort on thrombophilia (EPCOT). JTH 3:459-464

78. Brouwer JL, Lijfering WM, Ten Kate MK, Kluin-Nelemans HC, Veeger NJ, van der Meer J (2009) High long-term absolute risk of recurrent venous thromboembolism in patients with hereditary deficiencies of protein $\mathrm{S}$, protein $\mathrm{C}$ or antithrombin. Thromb Haemost 101:93-99

79. den Heijer M, Willems HP, Blom HJ et al (2007) Homocysteine lowering by B vitamins and the secondary prevention of deep vein thrombosis and pulmonary embolism: a randomized, placebo-controlled, double-blind trial. Blood 109:139-144

80. Verhovsek M, Douketis JD, Yi Q et al (2008) Systematic review: D-dimer to predict recurrent disease after stopping anticoagulant therapy for unprovoked venous thromboembolism. Ann Intern Med 149(481-490):W494

81. Douketis J, Tosetto A, Marcucci M et al (2010) Patient-level meta-analysis: effect of measurement timing, threshold, and patient age on ability of D-dimer testing to assess recurrence risk after unprovoked venous thromboembolism. Ann Intern Med 153:523-531

82. Cosmi B, Legnani C, Tosetto A et al (2010) Usefulness of repeated D-dimer testing after stopping anticoagulation for a first episode of unprovoked venous thromboembolism: the PROLONG II prospective study. Blood 115:481-488

83. Palareti G, Cosmi B, Legnani C et al (2014) D-dimer to guide the duration of anticoagulation in patients with venous thromboembolism: a management study. Blood 124:196-203

84. Tan M, Mos IC, Klok FA, Huisman MV (2011) Residual venous thrombosis as predictive factor for recurrent venous thromboembolim in patients with proximal deep vein thrombosis: a sytematic review. Br J Haematol 153:168-178

85. Le Gal G, Carrier M, Kovacs MJ et al (2011) Residual vein obstruction as a predictor for recurrent thromboembolic events after a first unprovoked episode: data from the REVERSE cohort study. JTH 9:1126-1132
86. Zhu T, Martinez I, Emmerich J (2009) Venous thromboembolism: risk factors for recurrence. Arterioscler Thromb Vasc Biol 29:298-310

87. Cushman M, Glynn RJ, Goldhaber SZ et al (2006) Hormonal factors and risk of recurrent venous thrombosis: the prevention of recurrent venous thromboembolism trial. JTH 4:2199-2203

88. White RH, Murin S, Wun T, Danielsen B (2010) Recurrent venous thromboembolism after surgery-provoked versus unprovoked thromboembolism. JTH 8:987-997

89. Douketis JD, Crowther MA, Foster GA, Ginsberg JS (2001) Does the location of thrombosis determine the risk of disease recurrence in patients with proximal deep vein thrombosis? Am J Med 110:515-519

90. Eichinger S, Weltermann A, Minar E et al (2004) Symptomatic pulmonary embolism and the risk of recurrent venous thromboembolism. Arch of Internal Medicine 164:92-96

91. Jimenez D, Diaz G, Marin E, Vidal R, Sueiro A, Yusen RD (2006) The risk of recurrent venous thromboembolism in patients with unprovoked symptomatic deep vein thrombosis and asymptomatic pulmonary embolism. Thromb Haemost 95:562-566

92. Boutitie F, Pinede L, Schulman S et al (2011) Influence of preceding length of anticoagulant treatment and initial presentation of venous thromboembolism on risk of recurrence after stopping treatment: analysis of individual participants' data from seven trials. BMJ 342:d3036

93. Rodger MA, Kahn SR, Wells PS et al (2008) Identifying unprovoked thromboembolism patients at low risk for recurrence who can discontinue anticoagulant therapy. CMAJ 179:417-426

94. Eichinger S, Heinze G, Jandeck LM, Kyrle PA (2010) Risk assessment of recurrence in patients with unprovoked deep vein thrombosis or pulmonary embolism: the Vienna prediction model. Circulation 121:1630-1636

95. Tosetto A, Iorio A, Marcucci M et al (2012) Predicting disease recurrence in patients with previous unprovoked venous thromboembolism: a proposed prediction score (DASH). JTH 10:1019-1025

96. Kyrle PA, Eichinger S (2012) Clinical scores to predict recurrence risk of venous thromboembolism. Thromb Haemost 108:1061-1064

97. Poli D, Palareti G (2013) Assessing recurrence risk following acute venous thromboembolism: use of algorithms. Curr Opin Pulm Med 19:407-412

98. den Exter PL, Kooiman J, Huisman MV (2013) Validation of the Ottawa prognostic score for the prediction of recurrent venous thromboembolism in patients with cancer-associated thrombosis. JTH 11:998-1000

99. Heit JA (2012) Estimating the incidence of symptomatic postoperative venous thromboembolism: the importance of perspective. JAMA 307:306-307

100. Yusuf H, Tsai J, Atrash HK, Boulet LP, Grosse SD (2012) Venous thromboembolism in adult hospitalizations - United States, 2007-2009. MMWR Morb Mortal Wkly Rep 61:401-404

101. Cohoon KP, Leibson CL, Ransom JE, et al (2015) Costs of venous thromboembolism associated with hospitalization for medical illness. Am J Manag Care 21(4):e255-e263

102. Cohoon KP, Leibson CL, Ransom JE, et al (2015) Direct medical costs attributable to venous thromboembolism among persons hospitalized for major operation: a population-based longitudinal study. Surgery 157:423-431

103. Cohoon KP, Leibson CL, Ransom JE, et al (2015) Direct medical costs attributalbe to cancer-associated venous thromboembolism: a population-based longitudinal study. J Oncol Pract 
104. Heit JA, Silverstein MD, Mohr DN, Petterson TM, O'Fallon WM, Melton LJ 3rd (1999) Predictors of survival after deep vein thrombosis and pulmonary embolism: a population-based, cohort study. Arch Intern Med 159:445-453

105. Goldhaber SZ, Visani L, De Rosa M (1999) Acute pulmonary embolism: clinical outcomes in the International Cooperative Pulmonary Embolism Registry (ICOPER). Lancet 353:1386-1389

106. Janata K, Holzer M, Domanovits H et al (2002) Mortality of patients with pulmonary embolism. Wien Klin Wochenschr 114:766-772

107. Andresen MS, Sandven I, Brunborg C et al (2011) Mortality and recurrence after treatment of VTE: long term follow-up of patients with good life-expectancy. Thromb Res 127:540-546

108. Agnelli G, Becattini C (2010) Acute pulmonary embolism. N Engl J Med 363:266-274

109. Konstantinides S, Geibel A, Olschewski M et al (1997) Association between thrombolytic treatment and the prognosis of hemodynamically stable patients with major pulmonary embolism: results of a multicenter registry. Circulation 96:882-888

110. Horlander KT, Mannino DM, Leeper KV (2003) Pulmonary embolism mortality in the United States, 1979-1998: an analysis using multiple-cause mortality data. Arch Intern Med 163: $1711-1717$

111. Tsai J, Grosse SD, Grant AM, Hooper WC, Atrash HK (2012) Trends in in-hospital deaths among hospitalizations with pulmonary embolism. Arch Intern Med 172:960-961

112. Heit JA, Silverstein MD, Mohr DN, Petterson TM, O'Fallon WM, Melton LJ 3rd (2000) Risk factors for deep vein thrombosis and pulmonary embolism: a population-based case-control study. Arch Intern Med 160:809-815

113. Cushman M, Folsom AR, Wang L et al (2003) Fibrin fragment D-dimer and the risk of future venous thrombosis. Blood 101:1243-1248

114. Smeeth L, Cook C, Thomas S, Hall AJ, Hubbard R, Vallance P (2006) Risk of deep vein thrombosis and pulmonary embolism after acute infection in a community setting. Lancet 367:1075-1079

115. Sweetland S, Green J, Liu B et al (2009) Duration and magnitude of the postoperative risk of venous thromboembolism in middle aged women: prospective cohort study. BMJ 339:b4583

116. Bezemer ID, van der Meer FJ, Eikenboom JC, Rosendaal FR, Doggen CJ (2009) The value of family history as a risk indicator for venous thrombosis. Arch Intern Med 169:610-615

117. Barsoum MK, Heit JA, Ashrani AA, Leibson CL, Petterson TM, Bailey KR (2010) Is progestin an independent risk factor for incident venous thromboembolism? A population-based casecontrol study. Thromb Res 126:373-378

118. Roach RE, Lijfering WM, Flinterman LE, Rosendaal FR, Cannegieter SC (2013) Increased risk of CVD after VT is determined by common etiologic factors. Blood 121:4948-4954

119. Heit JA, Melton LJ 3rd, Lohse CM et al (2001) Incidence of venous thromboembolism in hospitalized patients vs community residents. Mayo Clin Proc 76:1102-1110

120. Noboa S, Mottier D, Oger E (2006) Estimation of a potentially preventable fraction of venous thromboembolism: a communitybased prospective study. JTH 4:2720-2722

121. Samama MM (2000) An epidemiologic study of risk factors for deep vein thrombosis in medical outpatients: the Sirius study. Arch Intern Med 160:3415-3420

122. Geerts WH, Bergqvist D, Pineo GF et al (2008) Prevention of venous thromboembolism: American College of Chest Physicians Evidence-Based Clinical Practice Guidelines (8th Edition). Chest 133:381S-453S

123. Sweetland S, Parkin L, Balkwill A, Green J, Reeves G, Beral V (2013) Smoking, surgery, and venous thromboembolism risk in women: United Kingdom cohort study. Circulation 127:1276-1282
124. White RH, Zhou H, Romano PS (2003) Incidence of symptomatic venous thromboembolism after different elective or urgent surgical procedures. Thromb Haemost 90:446-455

125. Edmonds MJ, Crichton TJ, Runciman WB, Pradhan M (2004) Evidence-based risk factors for postoperative deep vein thrombosis. ANZ J Surg 74:1082-1097

126. Goldhaber SZ, Tapson VF (2004) A prospective registry of 5,451 patients with ultrasound-confirmed deep vein thrombosis. Am J Cardiol 93:259-262

127. Anderson FA Jr, Hirsh J, White K, Fitzgerald RH Jr (2003) Temporal trends in prevention of venous thromboembolism following primary total hip or knee arthroplasty 1996-2001: findings from the Hip and Knee Registry. Chest 124:349S-356S

128. White RH, Gettner S, Newman JM, Trauner KB, Romano PS (2000) Predictors of rehospitalization for symptomatic venous thromboembolism after total hip arthroplasty. N Engl J Med 343:1758-1764

129. Parkin L, Sweetland S, Balkwill A, Green J, Reeves G, Beral V (2012) Body mass index, surgery, and risk of venous thromboembolism in middle-aged women: a cohort study. Circulation 125:1897-1904

130. Mantilla CB, Horlocker TT, Schroeder DR, Berry DJ, Brown DL (2003) Risk factors for clinically relevant pulmonary embolism and deep venous thrombosis in patients undergoing primary hip or knee arthroplasty. Anesthesiology 99:552-560 discussion 555A

131. Zakai NA, Wright J, Cushman M (2004) Risk factors for venous thrombosis in medical inpatients: validation of a thrombosis risk score. JTH 2:2156-2161

132. Chopard P, Spirk D, Bounameaux H (2006) Identifying acutely ill medical patients requiring thromboprophylaxis. JTH 4:915-916

133. Barbar S, Noventa F, Rossetto V et al (2010) A risk assessment model for the identification of hospitalized medical patients at risk for venous thromboembolism: the padua prediction score. JTH 8:2450-2457

134. Rothberg MB, Lindenauer PK, Lahti M, Pekow PS, Selker HP (2011) Risk factor model to predict venous thromboembolism in hospitalized medical patients. J Hosp Med 6:202-209

135. Spyropoulos AC, Anderson FA Jr, Fitzgerald G et al (2011) Predictive and associative models to identify hospitalized medical patients at risk for VTE. Chest 140:706-714

136. Woller SC, Stevens SM, Jones JP et al (2011) Derivation and validation of a simple model to identify venous thromboembolism risk in medical patients. Am J Med 124(947-954):e942

137. Zakai NA, Callas PW, Repp AB, Cushman M (2013) Venous thrombosis risk assessment in medical inpatients: the medical inpatients and thrombosis (MITH) study. JTH 11:634-641

138. Samama MM, Combe S, Conard J, Horellou MH (2012) Risk assessment models for thromboprophylaxis of medical patients. Thromb Res 129:127-132

139. Rothberg MB (2014) Venous thromboembolism prophylaxis for medical patients: who needs it? JAMA Intern Med 174:15851586

140. Chew HK, Wun T, Harvey D, Zhou H, White RH (2006) Incidence of venous thromboembolism and its effect on survival among patients with common cancers. Arch Intern Med 166:458-464

141. Blom JW, Vanderschoot JP, Oostindier MJ, Osanto S, van der Meer FJ, Rosendaal FR (2006) Incidence of venous thrombosis in a large cohort of 66,329 cancer patients: results of a record linkage study. JTH 4:529-535

142. Kucuk O, Kwaan HC, Gunnar W, Vazquez RM (1985) Thromboembolic complications associated with L-asparaginase therapy. Etiologic role of low antithrombin III and plasminogen 
levels and therapeutic correction by fresh frozen plasma. Cancer 55:702-706

143. Liebman HA, Wada JK, Patch MJ, McGehee W (1982) Depression of functional and antigenic plasma antithrombin III (AT-III) due to therapy with L-asparaginase. Cancer 50:451-456

144. Zangari M, Anaissie E, Barlogie B et al (2001) Increased risk of deep-vein thrombosis in patients with multiple myeloma receiving thalidomide and chemotherapy. Blood 98:1614-1615

145. Knight R, DeLap RJ, Zeldis JB (2006) Lenalidomide and venous thrombosis in multiple myeloma. N Engl J Med 354:2079-2080

146. Meier CR, Jick H (1998) Tamoxifen and risk of idiopathic venous thromboembolism. Br J Clin Pharmacol 45:608-612

147. Tafur AJ, Kalsi H, Wysokinski WE et al (2011) The association of active cancer with venous thromboembolism location: a population-based study. Mayo Clin Proc 86:25-30

148. Carrier M, Le Gal G, Wells PS, Fergusson D, Ramsay T, Rodger MA (2008) Systematic review: the Trousseau syndrome revisited: should we screen extensively for cancer in patients with venous thromboembolism? Ann Intern Med 149:323-333

149. Khorana AA, Kuderer NM, Culakova E, Lyman GH, Francis CW (2008) Development and validation of a predictive model for chemotherapy-associated thrombosis. Blood 111:4902-4907

150. Ay C, Dunkler D, Marosi C et al (2010) Prediction of venous thromboembolism in cancer patients. Blood 116:5377-5382

151. Merrer J, De Jonghe B, Golliot F et al (2001) Complications of femoral and subclavian venous catheterization in critically ill patients: a randomized controlled trial. JAMA 286:700-707

152. Decousus H, Quere I, Presles E et al (2010) Superficial venous thrombosis and venous thromboembolism: a large, prospective epidemiologic study. Ann Intern Med 152:218-224

153. Goldhaber SZ, Savage DD, Garrison RJ et al (1983) Risk factors for pulmonary embolism. The Framingham Study. Am J Med 74:1023-1028

154. Cogo A, Bernardi E, Prandoni P et al (1994) Acquired risk factors for deep-vein thrombosis in symptomatic outpatients. Arch Intern Med 154:164-168

155. Dalen JE (2003) Economy class syndrome: too much flying or too much sitting? Arch Intern Med 163:2674-2676

156. Kuipers S, Cannegieter SC, Middeldorp S, Robyn L, Buller HR, Rosendaal FR (2007) The absolute risk of venous thrombosis after air travel: a cohort study of 8,755 employees of international organisations. PLoS Med 4:e290

157. Chandra D, Parisini E, Mozaffarian D (2009) Meta-analysis: travel and risk for venous thromboembolism. Ann Intern Med 151:180-190

158. Watson HG, Baglin TP (2011) Guidelines on travel-related venous thrombosis. Br J Haematol 152:31-34

159. Ray JG, Mamdani M, Tsuyuki RT, Anderson DR, Yeo EL, Laupacis A (2001) Use of statins and the subsequent development of deep vein thrombosis. Arch Intern Med 161:1405-1410

160. Lacut K, Oger E, Le Gal G et al (2004) Statins but not fibrates are associated with a reduced risk of venous thromboembolism: a hospital-based case-control study. Fundam Clin Pharmacol 18:477-482

161. Glynn RJ, Danielson E, Fonseca FA et al (2009) A randomized trial of rosuvastatin in the prevention of venous thromboembolism. N Engl J Med 360:1851-1861

162. Doggen CJ, Smith NL, Lemaitre RN, Heckbert SR, Rosendaal FR, Psaty BM (2004) Serum lipid levels and the risk of venous thrombosis. Arterioscler Thromb Vasc Biol 24:1970-1975

163. Prandoni P, Bilora F, Marchiori A et al (2003) An association between atherosclerosis and venous thrombosis. N Engl J Med 348:1435-1441

164. Marcucci R, Liotta AA, Cellai AP et al (2003) Increased plasma levels of lipoprotein(a) and the risk of idiopathic and recurrent venous thromboembolism. Am J Med 115:601-605
165. Tsai AW, Cushman M, Rosamond WD, Heckbert SR, Polak JF, Folsom AR (2002) Cardiovascular risk factors and venous thromboembolism incidence: the longitudinal investigation of thromboembolism etiology. Arch Intern Med 162:1182-1189

166. Sorensen HT, Horvath-Puho E, Pedersen L, Baron JA, Prandoni P (2007) Venous thromboembolism and subsequent hospitalisation due to acute arterial cardiovascular events: a 20-year cohort study. Lancet 370:1773-1779

167. Zoller B, Li X, Sundquist J, Sundquist K (2011) Venous thromboembolism does not share strong familial susceptibility with coronary heart disease: a nationwide family study in Sweden. Eur Heart J 32:2800-2805

168. Barsoum MK, Cohoon KP, Roger VL et al (2014) Are myocardial infarction and venous thromboembolism associated? Population-based case-control and cohort studies. Thromb Res 134:593-598

169. Folsom AR, Chamberlain A (2008) Lipoprotein(a) and venous thromboembolism. Am J Med 121:e17

170. Chamberlain AM, Folsom AR, Heckbert SR, Rosamond WD, Cushman M (2008) High-density lipoprotein cholesterol and venous thromboembolism in the Longitudinal Investigation of Thromboembolism Etiology (LITE). Blood 112:2675-2680

171. Chasan-Taber L, Stampfer MJ (1998) Epidemiology of oral contraceptives and cardiovascular disease. Ann Intern Med 128:467-477

172. Rosendaal FR (1999) Risk factors for venous thrombotic disease. Thromb Haemost 82:610-619

173. Gomes MP, Deitcher SR (2004) Risk of venous thromboembolic disease associated with hormonal contraceptives and hormone replacement therapy: a clinical review. Arch Intern Med 164:1965-1976

174. Grady D, Wenger NK, Herrington D et al (2000) Postmenopausal hormone therapy increases risk for venous thromboembolic disease. The Heart and Estrogen/progestin Replacement Study. Ann Intern Med 132:689-696

175. Grady D, Hulley SB, Furberg C (1997) Venous thromboembolic events associated with hormone replacement therapy. JAMA 278:477

176. Heit JA, Kobbervig CE, James AH, Petterson TM, Bailey KR, Melton LJ 3rd (2005) Trends in the incidence of venous thromboembolism during pregnancy or postpartum: a 30-year population-based study. Ann Intern Med 143:697-706

177. Adomaityte J, Farooq M, Qayyum R (2008) Effect of raloxifene therapy on venous thromboembolism in postmenopausal women. A meta-analysis. Thromb Haemost 99:338-342

178. van Hylckama Vlieg A, Helmerhorst FM, Rosendaal FR (2010) The risk of deep venous thrombosis associated with injectable depotmedroxyprogesterone acetate contraceptives or a levonorgestrel intrauterine device. Arterioscler Thromb Vasc Biol 30:2297-2300

179. Smith NL, Heckbert SR, Lemaitre RN et al (2004) Esterified estrogens and conjugated equine estrogens and the risk of venous thrombosis. JAMA 292:1581-1587

180. Scarabin P-Y, Oger E, Plu-Bureau G (2003) Differential association of oral and transdermal oestrogen-replacement therapy with venous thromboembolism risk. Lancet 362(9382):428-432

181. James AH (2009) Venous thromboembolism in pregnancy. Arterioscler Thromb Vasc Biol 29:326-331

182. Danilenko-Dixon DR, Heit JA, Silverstein MD et al (2001) Risk factors for deep vein thrombosis and pulmonary embolism during pregnancy or post partum: a population-based, casecontrol study. Am J Obstet Gynecol 184:104-110

183. Roach RE, Lijfering WM, van Hylckama Vlieg A, Helmerhorst FM, Rosendaal FR, Cannegieter SC (2013) The risk of venous thrombosis in individuals with a history of superficial vein thrombosis and acquired venous thrombotic risk factors. Blood 122:4264-4269 
184. Ludvigsson JF, Welander A, Lassila R, Ekbom A, Montgomery SM (2007) Risk of thromboembolism in 14,000 individuals with coeliac disease. Br J Haematol 139:121-127

185. Shantsila E, Lip GY, Chong BH (2009) Heparin-induced thrombocytopenia. A contemporary clinical approach to diagnosis and management. Chest 135:1651-1664

186. Tsai AW, Cushman M, Tsai MY et al (2003) Serum homocysteine, thermolabile variant of methylene tetrahydrofolate reductase (MTHFR), and venous thromboembolism: longitudinal Investigation of Thromboembolism Etiology (LITE). Am J Hematol 72:192-200

187. Den Heijer M, Lewington S, Clarke R (2005) Homocysteine, MTHFR and risk of venous thrombosis: a meta-analysis of published epidemiological studies. JTH 3:292-299

188. van Zaane B, Squizzato A, Huijgen R et al (2010) Increasing levels of free thyroxine as a risk factor for a first venous thrombosis: a case-control study. Blood 115:4344-4349

189. Severinsen MT, Engebjerg MC, Farkas DK et al (2011) Risk of venous thromboembolism in patients with primary chronic immune thrombocytopenia: a Danish population-based cohort study. Br J Haematol 152:360-362

190. Boyle S, White RH, Brunson A, Wun T (2013) Splenectomy and the incidence of venous thromboembolism and sepsis in patients with immune thrombocytopenia. Blood 121:4782-4790

191. Grainge MJ, West J, Card TR (2010) Venous thromboembolism during active disease and remission in inflammatory bowel disease: a cohort study. Lancet 375:657-663

192. Dentali F, Squizzato A, Brivio L et al (2009) JAK2V617F mutation for the early diagnosis of $\mathrm{Ph}$ - myeloproliferative neoplasms in patients with venous thromboembolism: a metaanalysis. Blood 113:5617-5623

193. Barbui T, Carobbio A, Cervantes F et al (2010) Thrombosis in primary myelofibrosis: incidence and risk factors. Blood 115:778-782
194. Folsom AR, Lutsey PL, Astor BC, Wattanakit K, Heckbert SR, Cushman M (2010) Chronic kidney disease and venous thromboembolism: a prospective study. Nephrol Dial Transplant 25:3296-3301

195. Kayali F, Najjar R, Aswad F, Matta F, Stein PD (2008) Venous thromboembolism in patients hospitalized with nephrotic syndrome. Am J Med 121:226-230

196. Brodsky RA (2008) Paroxysmal nocturnal hemoglobinuria: stem cells and clonality. Hematology. Am Soc Hematol Educ Program pp 111-115

197. Bacani AK, Gabriel SE, Crowson CS, Heit JA, Matteson EL (2012) Noncardiac vascular disease in rheumatoid arthritis: increase in venous thromboembolic events? Arthritis Rheum 64:53-61

198. Holmqvist ME, Neovius M, Eriksson J et al (2012) Risk of venous thromboembolism in patients with rheumatoid arthritis and association with disease duration and hospitalization. JAMA 308:1350-1356

199. Arnulf I, Merino-Andreu M, Perrier A, Birolleau S, Similowski T, Derenne JP (2002) Obstructive sleep apnea and venous thromboembolism. JAMA 287:2655-2656

200. Peng YH, Liao WC, Chung WS et al (2014) Association between obstructive sleep apnea and deep vein thrombosis/ pulmonary embolism: a population-based retrospective cohort study. Thromb Res 134:340-345

201. Austin H, Key NS, Benson JM et al (2007) Sickle cell trait and the risk of venous thromboembolism among blacks. Blood 110:908-912

202. Merkel PA, Lo GH, Holbrook JT et al (2005) Brief communication: high incidence of venous thrombotic events among patients with Wegener granulomatosis: the Wegener's Clinical Occurrence of Thrombosis (WeCLOT) Study. Ann Intern Med 142:620-626 